\title{
Peri-Urban Land Use Dynamics and Development Implications in the Bamenda III Municipality of Cameroon
}

\author{
Jude Ndzifon Kimengsi ${ }^{1 *}$, Balgah Sounders $\operatorname{Nguh}^{1} \&$ Achia Soulange Nafoin ${ }^{2}$ \\ ${ }^{1}$ Department of Geography, University of Buea, Cameroon \\ 2 Department of Geography, University of Bamenda, Cameroon \\ *Jude N. Kimengsi, E-mail: jude.kimengsi@catuc.org
}

Received: June 20, 2017

Accepted: June 30, 2017

Online Published: July 3, 2017

doi:10.22158/se.v2n3p273

URL: http://dx.doi.org/10.22158/se.v2n3p273

\begin{abstract}
A consequence of rapid and uncontrolled urbanization is the growth of the peri-urban environment. Peri-urban areas the world over are undergoing rapid changes in their land uses with significant development implications. In the present study, Bamenda III, a municipality of Cameroon, which forms part of the Bamenda Metropolis-a primate city par excellence, witnessed dramatic changes in its peri-urban zone. Such changes are exemplified by the multiplication of land uses, a reduction in agricultural land in favour of settlements and other infrastructural developments as well as wetland invasion. Using a systematic sampling of 100 inhabitants in the Bamenda III peri-urban zone, complemented by interviews and secondary data sources, we sought to investigate the evolution, drivers and development implications of peri-urban land use dynamics. The results showed that during the year 2000-2015, there was a reduction in agricultural land area from 2943ha to 1389ha and a corresponding increase in the area for settlements from 1389ha to 2943ha. A positive correlation was observed between population growth and peri-urban land use dynamics in Bamenda III. The observed dynamics has significant developmental implications in terms of future planning perspectives, future developments at the expense of agricultural land and further encroachments into wetlands. The study concludes that a coordinated and planned growth policy should be introduced in order to control rapid peri-urban land use change in the face of population growth.
\end{abstract}

\section{Keywords}

peri-urban, land use dynamics, development implications, Bamenda

\section{Introduction}

The world is becoming increasingly urbanized and half of humanity now lives in urban areas-more than $70 \%$ in Latin America, North America and Europe (UN-Habitat, 2008). The UNFPA (2007) contends that the space taken up by urban localities is increasing faster than the urban population itself. Between 2000 and 2030, the world's urban population is expected to increase by $72 \%$ while the built-up 
areas of cities could increase by $175 \%$. Urban regions the world over are grappling with the reality of a highly dynamic metropolitan growth and developmental dynamism that accompany such growth (Chirisa, 2009). These changes express themselves most evidently in peri-urban areas. The expansion of cities into peri-urban areas - a process that is commonly referred to as peri-urbanization leads to changes in land use patterns in such environments (Owusu, 2008).

Peri-urbanization equally relates to the process of urban sprawl which has spatial consequences especially as it threatens the use of space (Etxebarria \& Astorkiza, 2012, Galli et al., 2010). It further relates to the social, economic, cultural and environmental mutations that characterise peri-urban areas - a product of rapid and uncontrolled urbanization. These areas have assumed the central stage of physical, social and economic transformation both in developed and in the developing world (Webster, 2002). Dynamism in peri-urban environments are characterized by changing local economic and employment structures from agriculture to manufacturing, rapid population growth and migration, rising land values, mixed land uses and significant infrastructural development (Plurel, 2010). In advanced societies, the peri-urban is a zone of social and economic change and spatial restructuring, while in most parts of the developing world, it often denotes a zone of chaotic urbanization leading to sprawl (Ravetz et al., 2013). Peri-urban areas usually exist when urban residents acquire prime agricultural land at the urban fringes and use them for residential or commercial purposes (Appiah et al., 2014; Mandere et al., 2010; Samat et al., 2011).

The process of uncontrolled urbanisation which springs up in poverty is considered a catalystic factor for land use change in the peri-urban sphere. Peri-urban land development which goes on in an unregulated manner gives rise to complex urban structures which assume a horizontal expansion trajectory. The emerging land use pattern, by and large, indicates a mismatch with the widely cherished planning norms and standards and land value theories which underpin urban land use planning instruments such as zoning and density distribution and principles like the equitable provision of basic services, including complementarity in urban land development (Kombe, 2003). Furthermore, patterns of peri-urban growth seldom respect the laid down Master Plans and even the Master Plans show significant deviation from preferred land suitability (Dutta, 2012).

The process of uncontrolled growth in the peri-urban environment results in some cases in slum development characterised by the conspicuous absence of basic facilities to sustain the population. $62 \%$ of sub Saharan African urban population lives in slums where conditions of slums are quite defined in the peri-urban sphere and these slums have been associated with poverty and other environmental hazards (Chirisa, 2009). A visible aspect of peri-urbanisation is the process of land use dynamics characterised by a systematic shift from agricultural to residential, commercial and other land uses. Land use, the way human employ the land and its resources (Balgah, 2007) continue to witness significant transformations. Land use changes involve the transformation of diverse land use activities due to population increase and economic development (Zorrilla-Miras et al., 2014; Tijani et al., 2011).

The urban population in Cameroon doubled within a period of 30 years after independence moving 274 
from $28.3 \%$ in 1976 to $44.3 \%$ in 2005 (Fombe \& Balgah, 2012). This has resulted in rapid urban expansion of Cameroonian cities such as Yaounde, Douala, Bafoussam and Bamenda. The impact of the expansion of these cities is felt at the peripheries like Bikoko in Douala, Mile 16 in Buea, Barombi Kang in Kumba and Nkwen in Bamenda among others. Peri-urban dynamics in Cameroon is reflected through changes in land use, new forms of household composition, differential access to urban benefits (such as health infrastructure and employment) and increased pressure on common natural resources (Allen et al., 2006). Bamenda III which forms part of the Bamenda metropolis - a primate city par excellence has witnessed significant transformations in land uses within her peri-urban zone. Such changes are witnessed in agricultural, residential and commercial land uses among others. This dynamism calls for an investigation on their developmental implications.

\section{The Problem}

Peri-urban areas the world over are undergoing rapid changes in their land uses with significant development implications. Cameroon is one of the countries in Africa which is experiencing rapid urbanization with estimated urban dynamics of about $5 \%$ (NIS, 2000). This has led to the growth of towns and the peri-urban environments. Bamenda III which forms part of the Bamenda Metropolis- $\mathrm{a}$ primate city par excellence has witnessed peri-urban dynamics which is mirrored through the multiplication of land uses leading to a reduction in some land uses in favour of others. For instance, between the year 2000 and 2015, there was a reduction in the surface area for agriculture from 2943ha to 1389 ha and a corresponding increase in the surface area for settlements from 1389ha to 2943 ha. However, an important aspect which seemed to have eluded urban geographical literature or better still remains insufficient in the context of Bamenda, concerns scientific perspectives on the developmental implications of land use dynamics at the peri-urban environment. Previous research works have laid emphasis on the effect of urbanization on the wetland environment (Kometa \& Ndi, 2012; Ndi, 2010). Furthermore, researchers have sought to investigate agricultural production activities in Bamenda (Kamga, 2013; Wanyu, 2014). Therefore, the trends and implication need to be given due scientific attention. From 2000 to 2015, this peri-urban milieu has been experiencing changes as indicated by population, infrastructure, housing typology and agricultural land use. These changes are largely driven by a host of socio-economic and political factors, with population growth largely blamed for such developments. In this regard, it is necessary to understand the dynamics in land uses, their drivers and development implications. This is necessary so as to suggest measures to ensure the implementation of a coordinated and planned growth policy in the face of the seemingly inevitable changes in the Bamenda III peri-urban environment.

\section{Contextual Literature}

Urban fringe dynamics is used to explain the changes taking place at zones which are closer to the town and are characterised by a mixture of urban and rural characteristics. The continuous importance of the 
peri-urban zone is as a result of the limitation in the dichotomy between the rural and the urban areas. Duncan and Reiss (1956) considered the urban fringe as that area of the countryside which is in the process of transition from rural life to an urban life. So the fringe is the rural zone that is closer to the city which is gradually undergoing the process of change or the process of urbanization. This is visible in areas like Mile 5 Nkwen and the outskirts of Nkwen towards Nzah village, characterized by a gradual mixture of rural and urban activities leading to peri-urban dynamics.

Peri-urban as a term can represent a place, concept or process. As a place, it thus refers to the urban fringe and the geographic edge of cities; as a process, it refers to the movement of goods and services between physical spaces and to the transition from rural to urban contexts, and as a concept, it refers to an interface between rural and urban activities, institutions and perspectives (Narain \& Nischal, 2007). This view is shared by the Council of Europe (CEMAT, 2007) to involve the transition area moving from strictly rural to completely urban, related to a high pressure towards urban development. The term is further viewed by Bengs and Schmidt-Thome (2006) as something between, neither urban nor rural. The historical dichotomy of urban and rural space started to blur in Europe with the formation of nation states, industrialization and the liberalization of the economy in the nineteenth century. However, firstly with the introduction of mass commuter transport systems such as suburban railways, and finally with the increased affordability of cars, the countryside close to towns became a potential place for living, recreation and sometimes also working for former urbanites. In this regard, Simon et al. (2003) argues the peri-urban sphere in Africa should be considered as an area of complementarity because of the enduring socio-economic interrelationships between these areas and cities. Such studies demonstrate farmers' innovative responsiveness to - and dependence on - market forces.

In tracing the evolution of peri-urban dynamics, the UN Habitat (2008) contends that there are differences in the trends of peri-urbanisation and peri-urban dynamics in the developed and the developing world. In developing countries, urbanization started in 1945 and the rates have been constantly increasing. Kundu et al. (2002) consider the growth of peri-urban areas to arise from the segregation of a population between the core and the peripheries. In contrast, Bell et al. (2010) opined that demographic and social dynamics are the main causes of peri-urban dynamics. These demographic and social dynamics are driven by population change due to fertility and mortality rates and migration. This explains why population change is considered as one of the key factors of the dynamic nature of the Bamenda III municipality. It is in this light that Kundu et al. (2002) view the concentration of a population towards metropolitan centers and its diffusion to their peripheries to have resulted in many complex problems such as land scarcity, inward and outward mobility of labour, economic, social and spatial segregation of population between the core and periphery. These developmental issues call for concerted efforts to implement a coordinated land management system in the face of further growth.

An applicable concept in this study is the concept of counter urbanization. Counter urbanization relates to the movement of people from cities to the country side seeking for a better quality of life. Many still commute into the city to work but increasing numbers are moving to completely change their lifestyle 
and work in rural areas often by tele-working. Counter-urbanization has presented challenges for both urban and rural planners. The more densely populated an area is, the greater the level of out migration. Recent evidence suggests that migration away from the largest cities is continuing (Allison, 2005). The movement of people from the city was first associated with industrial restructuring and was facilitated by changes in transport infrastructure (Berry et al., 1980). Today, it has been recognized that counter-urbanization reflects a growing preference of some households for rural lifestyles. Urban areas are experiencing a net loss in population, in terms of surplus housing, over-capacity in public infrastructure and neighborhood decline and abandonment (Turok, 1999). In the rural areas on the other hand, the key concern is the impact of counter-urbanization on housing affordability (Barker, 2004). This is due to the fact that the in-migrants with their high incomes can easily pay for the prices levies on houses. Counter-urbanization can lead to locals facing adverse house price movement. This is exacerbated by the low levels of social housing provision in the rural areas and the constraints on the supply of new houses associated with the planning system (Lewis et al., 1991). In addition, counter-urbanization has been linked with the negative social effect related to both the anti-development stance of the incomers and the environmental consequences of increased commuting (Banister et al., 1999). The concept of counter urbanization is a reality in the study area as there is the putting in place of the socio-economic facilities such as the construction of new schools especially in the primary sector and hospitals leading to quality education and health. As more people solicit this fringe zone, there is the search for more land for construction, agriculture and infrastructural development.

\section{Study Area and Methods}

Bamenda III sub division (Figure 1) is the gateway to and from the Divisions of Boyo, Ngokentunjia, Bui and Donga Mantung. It is an important transit for passengers and goods to and from the North West Region. It is bounded by Tubah sub division to the west, Bamenda I Sub-Division to north, Bamenda II Sub Division to the east and Bafut to the south. It has a total area of $22.9 \mathrm{~km}^{2}$ and a population estimated at 150,000 inhabitants with a $6 \%$ increase per annum (Bamenda Ill Council, 2012). The urban space population is about 95,000 inhabitants. This population is largely cosmopolitan, made up of indigenous Nkwen and Ndzah people together with migrants from all over the North West, West and other Regions of Cameroon including Nigerians, Chadians, and Equatorial Guineans. Population increase has led to the extension of activities to the Peri-urban milieu as a result of increase in the demand for these services - this contributes to the functional dynamism and associated implications registered in the area. 
Table 1. Population Evolution in Bamenda III (2000-2015)

\begin{tabular}{lll}
\hline Year & Total Population & Population increase \\
\hline 2000 & 59294 & - \\
2001 & 63079 & 3785 \\
2002 & 67105 & 4026 \\
2003 & 71388 & 4283 \\
2004 & 75945 & 4557 \\
2005 & 80793 & 4848 \\
2006 & 85950 & 5157 \\
2007 & 91436 & 5486 \\
2008 & 97272 & 5836 \\
2009 & 103481 & 6209 \\
2010 & 110086 & 6605 \\
2011 & 117113 & 7027 \\
2012 & 124588 & 7475 \\
2013 & 132540 & 7952 \\
2014 & 141000 & 8460 \\
2015 & 150000 & 9000 \\
\hline
\end{tabular}

Note. Bamenda III Council Development Plan (2012).

A sample of 100 questionnaires were administered to the target population made up of landlords, tenants, traditional rulers, drivers business men, religious authorities, shop owners, bike riders and hawkers who were selected randomly from the four villages considered for the study. These four villages (Membu, Mbelewa, Mbessi, \& Menteh) which were judged to have witnessed significant dynamics were purposively chosen. We then employed a systematic sampling of 100 household heads drawn from these villages. Within each village, we systematically sampled household heads from every $8^{\text {th }}$ household. Furthermore, interviews were conducted to the Mayor of Bamenda III council and the Paramount Fon of Nkwen who further traced the history of peri-urban growth in Bamenda III. These data, complemented by field observations and secondary data sources (population, land use dynamics, and infrastructural development) constituted the data source for this study. 


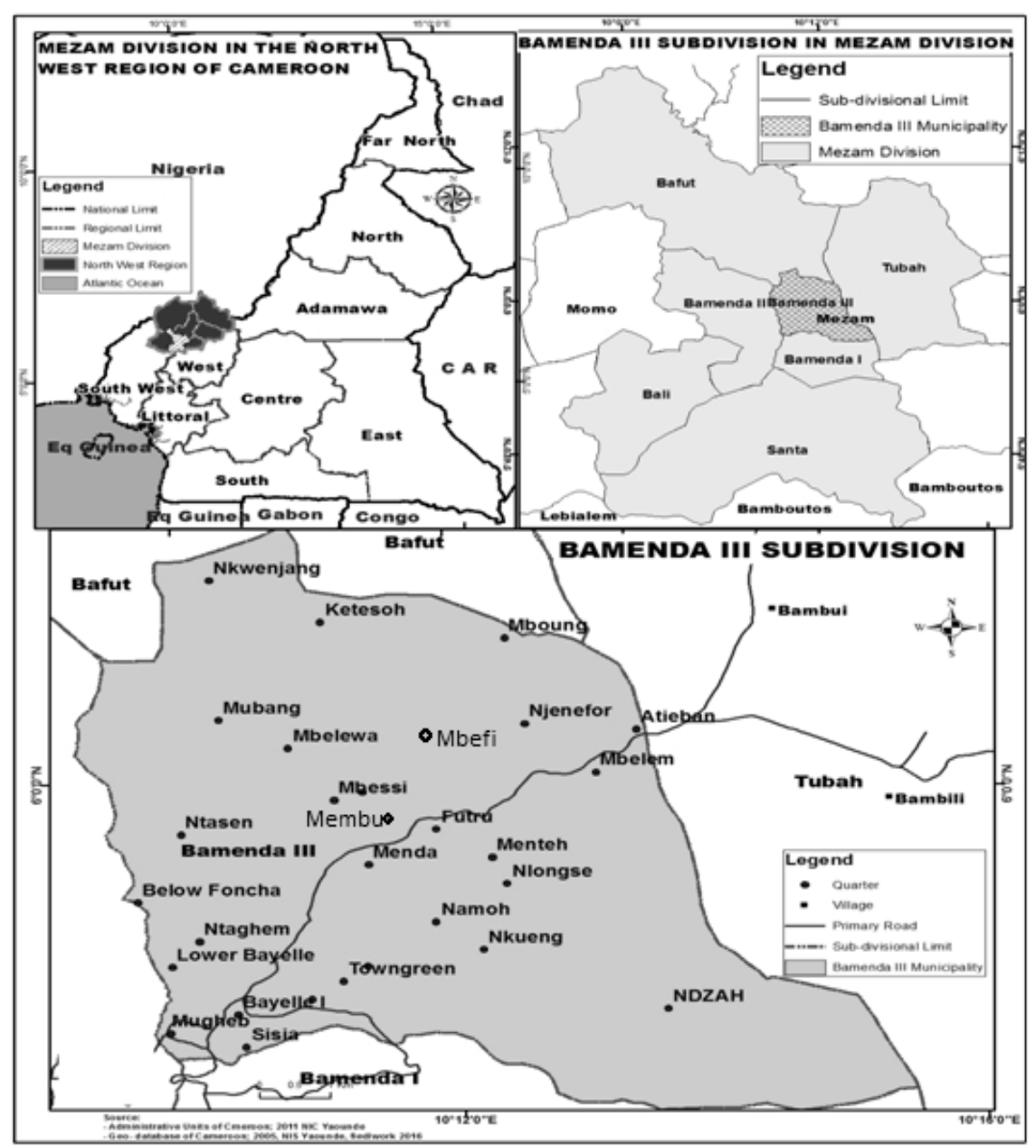

Figure 1. Location Map Bamenda III

Source: Adapted from Bamenda III council map.

To determine changes in land uses, land use maps for 2000 and 2015 were developed with the aid of Satellite Images (Landsat of 1990 and Google Earth Images for 2013) which were further supported by field work. This assisted in the analysis of dynamics in the Bamenda peri-urban zone as it portrayed the changes taking place with respect to settlement expansion, commercial and other social and infrastructural developments in the study area. Previous and current maps of the municipality were analyzed so as to understand the spatial evolution of land use at the Peri-urban milieu of Bamenda III and to appreciate their development implications. In addition, descriptive and inferential statistical tools were used to analyse the data with the aid of the Stata 11.1 Statistical package.

\section{Results and Discussion}

\subsection{Trends in Peri-Urban Dynamics}

Bamenda III urban area has been facing an outward expansion into the peri-urban area especially in the north and northwest borders of Nkwen and Ndzah. There has been a change in land uses especially 
from a predominantly agrarian land use to different land uses such as residential and commercial land uses. Significant dynamics in the study area can be appreciated at the northern and south western borders of the municipality.

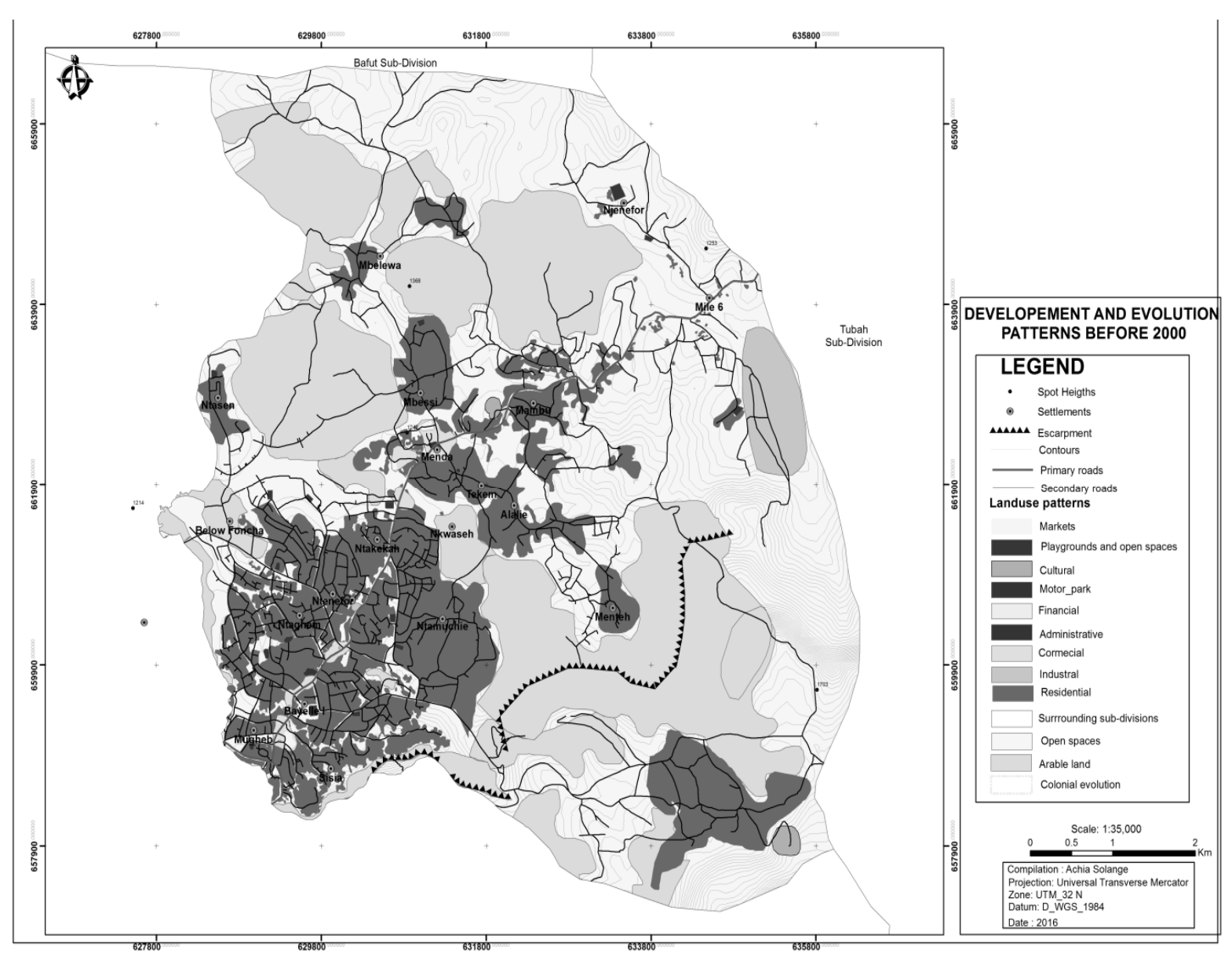

Figure 1. Peri-Urban Land Use Situation of Bamenda III in the Year 2000

Source: Adapted from Bamenda III Council Map.

As of the year 2000, the limit of the peri-urban zone of Bamenda III could be traced to include villages at the northern portion of the municipality such as Mambu, Ntassen and Mbessi where agriculture was the dominant land use (Figure 1). With the passage of time, other land uses multiplied and started competing with agricultural land use. For over 15 years (2000-2015), there has been a significant change in the land use picture of the peri-urban area from a purely agrarian to a semi urban zone characterized by a mixture of rural and urban traits. In this light, agricultural land use has been drastically reduced giving way to other activities such as settlement development, commercial activities, transport and communication infrastructure. 


\subsection{Dimensions of Evolution in the Peri-Urban Fringe of Bamenda III}

The evolution in land use in Bamenda III peri-urban zone has been classified in two dimensions which are, economic (agriculture and commerce) and social (population, education and housing infrastructure). With regards to health, prior to the year 2000, there was only one health centre serving the peri-urban area of Bamenda III (Bamenda III CDP, 2012). This has increased after 2000 giving a doctor population ratio of 1:230 as against 1:690 before 2000. Before the year 2000, the study area was interconnected with foot paths and most of the roads were seasonal. By 2015, the peri-urban zone has been interconnected with motorable roads. As from the year 2000, roads have been opened and graded, there has equally been the construction of bridges linking quarters like Atiala and Mbellewa. In the commercial sector, most of the people in the Bamenda III urban fringe depended on the Bamenda urban environment for the purchase of goods and services before 2000. Between 2000 and 2015, there has been the emergence of a wide range of good and services provided in Bamenda III urban fringe like mile 4 junction and pack, mile 5 junction and mile 6 . These include shops, offices in which retail and wholesale goods and services are provided.

Before 2000, the study area was predominantly an agrarian economy. As from the year 2000 to 2015, there has been an evolution in land use. In 2000, the total surface area covered by agricultural land use was estimated at 2943 hectares while that of settlement stood at 1227 hectares. As from the year 2000 to 2015 there has been a reduction in agrarian land use from 2943 to 1389 hectares and a corresponding increase in infrastructural land use area from 1389 to 2943 hectares (Figure 2). The agricultural system has witnessed an evolution in terms of surface area under construction and farming methods. This has led to the intensification of crop cultivation due to limited land as most of the land is now used for housing infrastructure. Such intensification is characterised by the high application of inputs like fertilizers, manure, for the cultivation of crops like maize, beans, vegetables and a reduction in cultivation areas at the expense of housing and commercial activities. Areas like Melewa, Menteh, Manka, Mambu, Atiela and Ngenefor that were predominantly agrarian are now being dominated by housing infrastructure and the reduction in agricultural land has led to the intensification of agriculture with the cultivation of crops like maize, potatoes, and market gardening. 


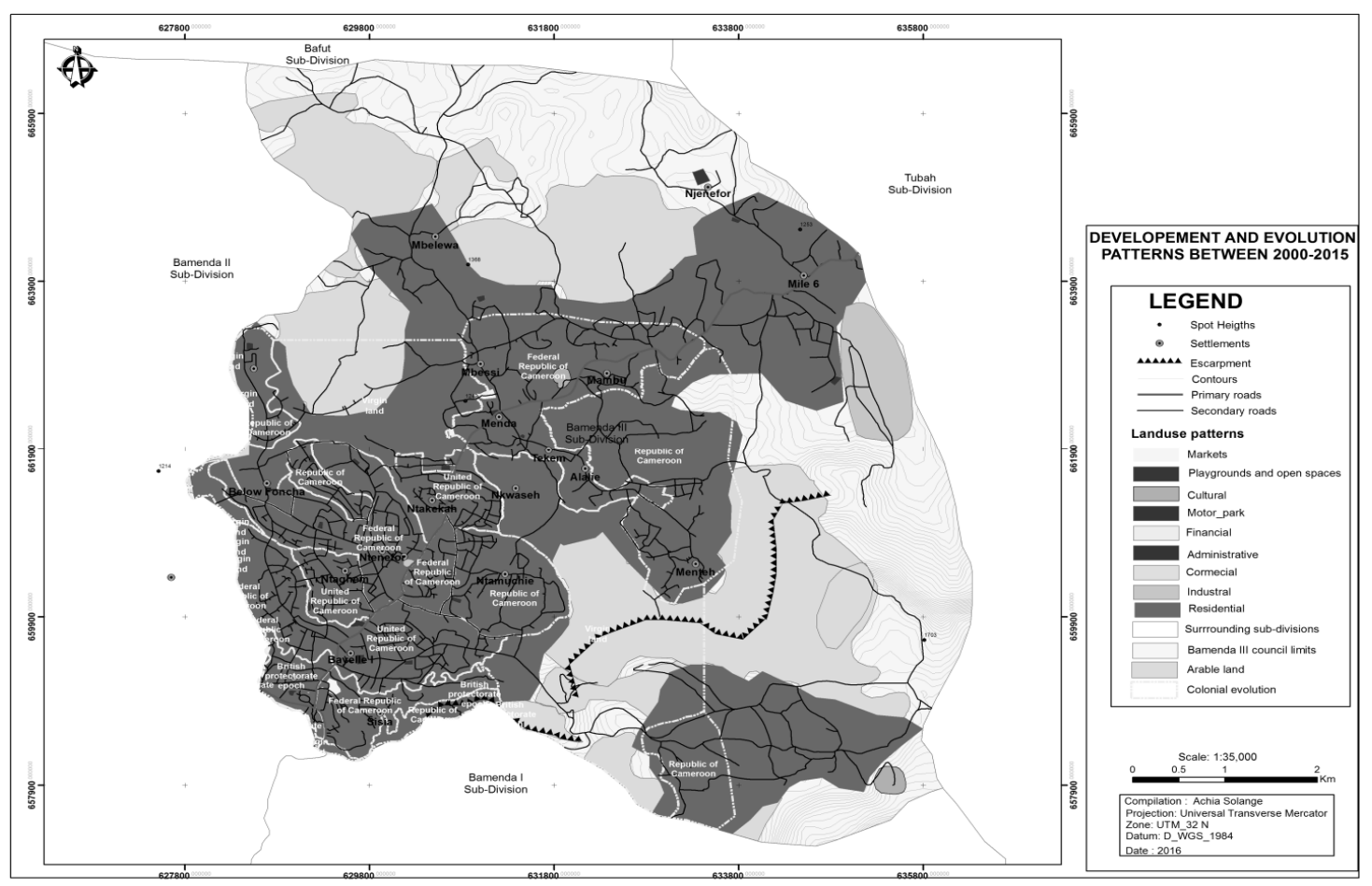

Figure 2. Peri Urban Land Use Situation of Bamenda III in 2015

Source: Adapted from Bamenda III council map, 2016.

\subsection{Drivers of Peri-Urban Land Use Dynamics}

The factors responsible for this conversion are economic, social and political. Amongst these factors, population growth is the main factor responsible for peri-urban dynamics in Bamenda III. This section presents the role of population growth and other factors responsible for peri-urban dynamism in the Bamenda III rural-urban fringe. Social factors play an important role in the conversion of land from agrarian to residential and commercial uses. These factors contribute $40 \%$ of the factors responsible for peri-urban dynamism in Bamenda III. These factors include population increase, increase in the demand for housing, increase in religious activities, and an increase in the demand for educational infrastructure. Bell et al. (2010) opined that demographic and social dynamics are the main causes of peri-urban dynamics. These demographic and social dynamics are driven by population change due to fertility and mortality rates and migration. Population change is one of the key factors of the dynamic nature of Bamenda III municipality. The population of Bamenda III increased from 59294 in 2000 to 150,000 as of 2015. Such an increase in population led to the increase in the demand for space to accommodate land uses, especially settlement land uses. The creation of schools is another domain or area of urban dynamics which has been championed by the missionaries. These schools range from Nursery, primary and secondary schools. Here the Catholics, the Baptist and the Full gospel mission have contributed by constructing schools accommodating over 4000 pupils and students. The number of schools increased from 15 to over 50 schools between 2000 and 2015 (Bamenda III Council Development Plan, 2012). The construction of these secondary schools have also contributed to 
peri-urban dynamics of the study area as it now gives a new look and at the same time converting the previous natural and agricultural land use to an infrastructural land use. The construction of health units is another dimension of peri-urban dynamics in the study area that is being orchestrated by the missionaries. (Bamenda III CDP, 2012).

According to Korcelli et al. (2011) economic structures and employment patterns also affect the trends of peri-urbanization. Field investigations hold that economic factors have contributed to $50 \%$ of the changes that have taken place in the study area. The most common economic factors here include commercial activities, transport and communication. These factors have different percentages of contribution to peri-urban dynamics. This sector has a $70 \%$ influence in the dynamics taking place in the study area. Commerce in the study area include small scale stores that trade in different types of goods, hawkers as well as a host of activities of the informal sector. Transport and communication contributed immensely to peri-urban dynamism in the study area. This is viewed through the construction of roads linking up the urban area of Bamenda III to the rural areas like Nzah, and Mambu. It has facilitated the movement of people from the peri-urban area as well as from the urban to the peri-urban. The transport sector has also been improved upon by the increase in motor bikes and taxis which help in transporting people from the rural area to the peri-urban area and from the urban to the peri-urban areas. The increase in these motor bikes as well as township taxis and good road network has improved on the changes taking place in the study area. With the development of communication especially through the mobile phone, many call box operators have set up call box activities which have also improved on the beauty of the town.

The creation of administrative units is seen as another contributing factor to peri-urban dynamics. The creation of Bamenda III sub-division also led to the creation of administrative units such as the Bamenda III council as well as the construction of security posts (Gendarmerie Brigade and the police station) at Mile 4 Nkwen. There is also the construction of government primary secondary schools which has led to the transformation of the area. This view is shared by Woltjer et al. (2014) who contend that urban regions worldwide are increasingly facing the challenge of dealing with highly dynamic metropolitan growth and, at the same time, institutional changes like decentralization. These kinds of changes express themselves most evidently in peri-urban areas, where urban and rural life meets.

\subsection{Development Implications of Peri-Urban Dynamics}

According to Allen (2003), economic changes in the peri-urban areas generally demonstrate a shift from an agriculturally-based to a manufacturing dominated economy, or a shift towards economic activities of higher productivity. Peri-urban dynamism in the Bamenda III urban fringe has positive implication in development. This is in the domain of transport, health, education and housing infrastructure as well as on commercial activities.

Increase in educational infrastructures is an outcome of peri-urban dynamism in the Bamenda III urban fringe. Field data revealed that this aspect constitute $15 \%$ of the positive outcome of peri-urban 
dynamism. This can be seen in all aspects of education beginning from primary, secondary and higher education. This is indicated by an increase in the number of institutions at all levels leading to a significant increase in the enrolment of students and pupils as compared to the situation before the year 2000. There is also an increase in the number of institutions of higher learning such as the National Polytechnic and the Bamenda University of Science and Technology (BUST). There has also been an increase in professional education as new professional institutions have been created in the study area such as the school of forestry which train student on forestry techniques or forest management techniques. More health facilities have been introduced to improve on health care accessibility. Patients are able to have access to health care not only because they are close to the hospital but due to improved road network. The maximum distance covered by a patient to the nearest health center found in the study area is $5 \mathrm{Km}$. Between 2000 to 2015, as a result of the improvement in road infrastructure, people travel easily to obtain health services without any difficulty. At first, most hospitals were linked by foot paths. Presently, most of the patients go to the hospital using various transports means as motor bikes, taxis and private cars. Commercial activities have been intensified in the study area and this is one of the indicators of urban dynamics or changes in the study area. These commercial activities have been stimulated in the following dimensions - an increase in economic activities and employment. Economic activities are seen in the domain of retail activities which form $25 \%$ of economic activities in the study area. Retailing is done in small shops which supply basic needs to the people. There is also an increase in the informal sector such as the sales of roasted maize and fish, hawking, call box operations. These activities have contributed to $62.5 \%$ of employment in the study area. There is also an increase in whole sale activities. This is contrary to the case that was before the year 2000 as there is now the presence of wholesale shops.

Improvement in transport infrastructure is one of the positive impacts of peri-urban dynamics in the study area. This is reflected in the construction of new roads as well as the construction of new motor parks such as the Mile 4 Motor Park. There has also been an increase in the construction of inter quarter roads such as the road linking Atiela and Mbellewa. This facilitates interaction between the peri-urban area, the urban area and the rural area which assist in the supply of food to the city dwellers. One of the positive implications of the peri-urban dynamics is agricultural intensification. This is through the application of fertilizer in the cultivation of crops. Field investigations reveal that $90 \%$ of the farmers at the peri-urban zones Cultivate beans, maize and potatoes. Before the year 2000, there were extensive areas for cultivation but with the reduction of agricultural land, farmers have resorted to intensive cultivation of crops like vegetables, maize and beans with the heavy application of inputs such as fertilizer.

Table 2 reports statistics on the development implications of peri-urban dynamics. About $66 \%$ of the sample claim that peri-urbanisation has improved accessibility to services and facilities in Bamenda III, while $27 \%$ believe it has improved the road network. Only $7 \%$ think it has improved the construction of motor parks. To all respondents, peri-urban dynamics has caused wetland invasion. For $68 \%$ of the 
sample, construction of houses and schools are the main peri-urban indicators that have invaded the agricultural land. For $32 \%$, the invasion of wetland is mainly for the cultivation of crops especially maize and vegetables. The results also indicate that peri-urban dynamics has significant implications on biodiversity, water, and other natural resources.

Table 2. Summary Statistics on the Development Implications

\begin{tabular}{llllll}
\hline Variables & Obs. & Mean & Std. Dev & Min & Max \\
\hline Peri-urbanisation improves accessibility & 65 & 0.66 & 0.48 & 0 & 1 \\
Peri-urbanisation improves road construction & 26 & 0.27 & 0.44 & 0 & 1 \\
Peri-urbanisation improves park construction & 7 & 0.07 & 0.26 & 0 & 1 \\
Dumpsites contaminate, pollutes, produce bad odour & 98 & 1.00 & 0.00 & 4 & 4 \\
Instances of climate change witnessed & 98 & 1.00 & 0.00 & 1 & 1 \\
Invaded land is used for house construction & 65 & 0.66 & 0.47 & 0 & 1 \\
Invaded land is used for crop cultivation & 31 & 0.32 & 0.47 & 0 & 1 \\
Invaded land is used for school construction & 2 & 0.02 & 0.14 & 0 & 1 \\
\hline
\end{tabular}

Source: field work 2016.

\section{Conclusion and Recommendations}

This paper sought to investigate the development implications of peri-urban land use dynamics in Bamenda III. Results show that significant peri-urban dynamics in Bamenda III began in the year 2000 and was characterized with a reduction in agricultural land use in favour of settlement - with an annual change of 52.6 percent characterized by increase in housing infrastructure and social infrastructure such as roads, schools and hospitals. Between 2000 and 2015, there was a reduction in the surface area for agriculture from $2943 \mathrm{ha}$ to $1389 \mathrm{ha}$ and a corresponding increase in the surface area for settlements from 1389 ha to $2943 \mathrm{ha}$. With a $5 \%$ margin of error, a positive correlation was established between population growth and peri-urban dynamics in Bamenda III which has significant developmental implications in terms of future planning perspectives, future developments at the expense of agricultural land and the further encroachments into wetlands. Furthermore, a coordinated and planned growth policy should be strictly employed in order to stem some of the negative effects of peri-urban dynamics. Based on these, the following recommendations are proposed:

There should be a strict enforcement of town planning and housing regulation to coordinate land use activities in Bamenda III. The council and the traditional authorities can support this process. The council and transport authorities should ensure that community road maintenance with the use of manual tools is done regularly. Furthermore, effective decentralization of power and authority to local government can enhance better local participation and encourage democratic practices with respect to deciding on the best use of land and controlling rapid expansion. Decentralization can improve the 
effectiveness of public implementation and produce policies and programmes that are both efficient and responsive to local preferences and needs for the peri-urban dwellers. Therefore, town planners and urban policy makers in Bamenda need to deeply reflect and consider this dispensation. Decentralized land management anchored on the subsisting local government administrative structures, introduction of user-friendly and pro-poor land regularization systems, and embarking on land banking by local authorities which have worked well in other contexts could be tailored and applied in the case of Bamenda III. The council in collaboration with traditional authorities should work towards the establishment of land development and subdivision control regulations to limit encroachment on agricultural land while adopting housing intensification measures. This could stem the problem of over reduction in agricultural land uses.

\section{References}

Allen, A. (2003). Environmental Planning and Management of Peri-urban Interface: Perspective on an Emerging Field. Environment and Urbanization, 15(1), 135-148. https://doi.org/10.1177/095624780301500103

Allen, A. et al. (2006b). The Peri-urban Water Poor: Citizens or Consumers? Environment and Urbanization, 18(2), 333-351. Action in Metropolitan Regions, Development Planning Unit, London. https://doi.org/10.1177/0956247806069608

Allen, A., \& Dávila, J. D. (2002). Mind the Gap: Bridging the Rural-urban Divide. Brighton: Institute of Development Studies.

Appiah, D. O., Bugri, J. T., Forkuo, E. K., \& Boateng, P. K. (2014). Determinants of Peri-Urbanization And Land Use Change Patterns In Peri-Urban Ghana. Journal of Sustainable Development, 7. https://doi.org/10.5539/jsd.v7n6p95

Balgah, S. N. (2007). Population Growth and land use dynamics in Buea Urban Area, Cameroon. Loyola Journal of Social Sciences, XXI(1), 103-115.

Bell et al. (2010). Migration and land use change in Europe. A Review. Living Review Landscape Resource. https://doi.org/10.12942/lrlr-2010-2

Bengs, C., \& Schmidt-Thome, K. (2006). ESPON 1.1.2. Urban-Rural relations in Europe (Final report). ESPON, Luxembourg.

CEMAT. (2007). Spatial development glossary. Council of Europe, Strasbourg.

Champion, A. G. (Ed.). (1989). Counter-urbanization. Edward Arnold, London.

Chirisa, I. (2008). Population growth and rapid urbanization in Africa: Implications for sustainability (Vol. 10, No. 2). J. Sustain. Dev. Afr. Clarion University of Pennsylvania. Clarion: Pennsylvania.

Chirisa, I. (2009). Prospects for the asset-based community development approach in Epworth and Ruwa, Zimbabwe: A housing and environmental perspective. Afr. J. Hist. Cult (AJHC), 1(2), 28-35.

Chirisa, I. (2010). Peri urban dynamics and regional planning in Africa: Implications for healthy cities. 
Journal of African studies and development, 2, 15-26.

Davis, M. (2004). Planet of Slums. New Left Review, 26.

Duncan, O. D., \& Reiss, A. J. (1956). Suburbs and Urban Fringe. In Social Characteristics of Urban and Rural Communities. New York.

Dupont, V. (2005). Peri-Urban Dynamics: Population, Habitat and Environment on the Peripheries of Large Indian Metropolises: An Introduction. In Dupont, A Review of Concepts and General Issues. New Delhi: Centre de Sciences Humaines.

Dutta, V. (2012). Land Use Dynamics and Peri-urban Growth Characteristics: Reflections on Master Plan and Urban Suitability from a Sprawling North Indian City. Environment and Urbanization Asia September 2012, 3(2), 277-301. https://doi.org/10.1177/0975425312473226

Etxebarria, A., \& Astorkiza, I. (2012). Are Land Use Policies Preserving Farmland From Urban Sprawl? Review of European Studies.

Firman T. (2000). Rural o Urban Land Conversion in Indonesia during Boom and Bust Periods. Land Use Policy, 17, 13-20. https://doi.org/10.1016/S0264-8377(99)00037-X

Galli, M., Lardon, S., Marraccini, E., \& Bonari, E. (2010). Agricultural Management in Peri-Urban Areas. In F. E. Srl (Ed.), The Experience Of An International Workshop.

Hadalah et al. (2007). Peri Urban in East Africa, Asia; A New Challenge for planning? Journal International Development Planning Review, 29(4), 503-519. https://doi.org/10.3828/idpr.29.4.4

Iaquinta, D. L., \& Drescher, A. W. (2000). Defining Peri-urban: Understanding Rural Urban Linkages and Their Connection to Institutional Contexts, Partnership Programme of the Food and Agriculture Organization of the United Nations (FAO).

Kombe, W. J. (2003). Land use dynamics in peri-urban areas and their implications on the urban growth and form: The case of Dar es Salaam, Tanzania. Habitat International, 29(1), 113-135. https://doi.org/10.1016/S0197-3975(03)00076-6

Korcelli et al. (2011). Economy and Development: Rural Urban Regions and Peri-Urbanization. In Europe: Academic Book Life Sciences. Copenhagen.

Kurtz, R. A., \& Eicher, J. B. (1958). Fringe and Suburb: A Confusion of Concept. In Social Forces (No 37). https://doi.org/10.2307/2573776

Maciocco, G. (2008). The territorial future of the city [electronic resource].

Mandere, M. N., Ness, B., \& Anderberg, S. (2010). Peri-Urban Development, Livelihood Change and Household Income: A Case Study Of Peri-Urban Nyahururu, Kenya. Journal of Agricultural Extension and Rural Development, 2, 73-83.

McIvor, C. (2001). Do not look down on us: Child researchers investigate informal settlements in Zimbabwe. PLA Notes, 7(42), 34-38.

Narain, V., \& Nischal, S. (2007). The Peri-Urban Interface in Shahpur Khurd and Karnera, India. Environment and Urbanization, 19(1), 261-273. https://doi.org/10.1177/0956247807076905

Owusu, G. (2008). Indigenes and Migrants' Access to Land In Peri-Urban Areas Of Accra, Ghana. 
International Development Planning Review, 30, 177-198. https://doi.org/10.1177/0956247807076905

Ravetz, J., Fertner, C., \& Nielsen, T. S. (2013). Peri-Urban Futures: Scenarios and Models For Land Use Change In Europe. In K. Nilsson, S. Pauliet, S. Bell, C. Aalbers, \& T. S. Nielsen (Eds.), Remaking Cities Contradictions of the Recent Urban Environment. New York, USA and Canada: Routledge Publications.

Samat, N., Hasni, R., Elhadary, E., \& Abdalla, Y. (2011). Modelling Land Use Changes at The Peri-Urban Areas Using Geographic Information Systems And Cellular Automata Model. Journal of Sustainable Development, 4, 72-84. https://doi.org/10.5539/jsd.v4n6p72

Simon et al. (2003). Poverty Elimination, North-South Research Collaboration, and the Politics of Participatory Development. Development in Practice, 13(1), 40-56. https://doi.org/10.1080/0961452022000037973

Simon, D. (2006). The peri-urban interface: Approaches to sustainable natural and human resource use. Earthscan, London.

Simon, D. (2008). Urban Environments: Issues on the Peri-Urban Fringe. Annual. Review the Environmental Resource, 33, 167-185. https://doi.org/10.1146/annurev.environ.33.021407.093240

Tijani, M. N., Olaleye, A. O., \& Olubanjo, O. O. (2012). Impact of Urbanization on Wetland Degradation. A Case Study of Eleyele Wetland Ibadan, South West Nigeria.

UNFPA. (2007). The Social and Sustainable Use of Space: Unleashing the Potential of Urban Growth. State of the World Population 2007. https://doi.org/10.18356/c9328977-en

UNFPA. (2008). State of World Population 2007: Unleashing the Potential of Urban Growth. UNFPA. University College.

Walt, G. (1994). Health Policy-An introduction to process and power. Zed Books: London.

Webtser, D. (2002). On the Edge: Shaping the future of Peri-urban East Asia. Stanford: Stanford University Press.

Woljer, J. (2014). A global review on peri urban development and planning, 25(1), 1-16, April 2014.

Zorrilla-Miras, P., Palomo, I., Gómez-Baggethun, E., Martín-López, B., Lomas, P. L., \& Montes, C. (2014). Effects of land-use change on wetland ecosystem services: A case study in the Doñana marshes (SW Spain). Landscape and Urban Planning, 122, 160-174. https://doi.org/10.1016/j.landurbplan.2013.09.013 